\title{
Promoting STEM Careers and ICT4D by Using Robotics to Reduce the Gender Gap in a Rural Region
}

\author{
Arnoldo Rodríguez, Rogelio Nájera \\ Universidad de Costa Rica \\ Costa Rica
}

\begin{abstract}
Costa Rica is a country with more than 800 companies linked to Information and Communication Technologies (ICT), but they face a shortage of qualified human resources and most companies are located in the center of the country. In addition, the participation of women is small in those enterprises and in science and technology in general. In Turrialba, a rural region, a local private initiative proposes alternative solutions that include robotics for improving technology literacy and social and economic development. An additional challenge is decreasing a "brain drain" of Computer Science (CS) graduates who migrate to the center of the country, because of the absence of enough ICT opening jobs in rural areas. In spite of the emigration of skilled workforce, many students want to be admitted in a CS program in Turrialba but admission to it is restricted. Opening admission for students interested in science, technology, engineering and mathematics (STEM) related programs in colleges is a difficult task, but opening opportunities for female students and fostering their interests about STEM is an even harder task.
\end{abstract}

\section{Introduction}

In Turrialba, a rural area of Costa Rica with 70000 inhabitants, the University of Costa Rica (UCR) used public funds for an educational robotics project intended to improve technological literacy of students and teachers. When public funds dried up, private companies and other public agencies supported the creation of a private local organization intended to promote technological literacy as a way to help define the role of Information and Communication Technologies (ICT) for development there.

This organization developed different activities including the design of a curriculum conducive to training technicians on cognitive robotics and maintenance of computers. This is an attempt to provide young people, particularly women, with an option to work in knowledge-intensive activities.

However, opening new opportunities in the knowledge society is not the only challenge for that organization because its scope includes promoting options of education and employment for a rural region as Turrialba.

\section{Problem}

Costa Rica was the fourth-largest exporter of technology in the world, according to the World Bank's World Development Indicators 2010. In comparison to most other Latin American countries, ICT sector was larger in Costa Rica [1].

A complementary view is summarized by [2]: "Costa Rica is fairly well poised to engage in a rapid transition toward more knowledge-based activities. The country boasts one of the best education systems in the region (Central America); a fairly high ICT uptake with a high international Internet bandwidth capacity and many mobile broadband subscriptions; and a fairly well developed capacity to innovate and solid access to technology, thanks to the crucial role that FDI and technology transfer plays in the country". Exports linked to ICT sector were 20 per cent of the country total exports in 2011.

Now, to achieve said transition, Costa Rica faces a deficit of more than 40 per cent of the ICT related workforce [3]. Another difficulty is that the contents of some ICT programs in universities are outdated by up to six years in comparison with current requirements of software developers.

In addition, Costa Rica will need 36000 new technicians to fulfill the needs of industries and, currently, only 3,4 per cent of the total workforce has formal technical training [4].

In spite of the fact that only 34 per cent of the workforce finished high school and 64 per cent are unqualified workers [5], the human-capital endowment is considered "the country's main competitive advantage".

Additionally, an important part of the public universities supports programs with limited labor opportunities. Unemployment is high in social sciences related jobs in which more people obtain diplomas. Meanwhile, unemployment in areas linked to engineering is lower and incomes in this area are higher than jobs related to social sciences. Furthermore, attracting students to ICT related programs in colleges is a difficult task, but opening opportunities for female students and fostering their interests about ICT is a harder job. 
Moreover, budget policies restrict the number of openings for people who want to study Computer Science (CS) programs in public universities. In many rural areas, there are public CS programs, but ICT companies are located in urban zones of the center of the country. As a consequence, graduates in CS leave rural areas looking for work in urban areas and that "brain drain" does not help attract resources for local social and economic development.

To make matters worse, the central government and public agencies do not apply efficient policies to attract more investors to rural zones. More software developers could be convinced to move to poor rural areas and take advantage of the local pipeline of CS graduates (e.g. Turrialba), linking them to the local economy.

\subsection{Purpose}

This paper tries to foresee what should be the role of ICT for development (ICT4D) for a rural region where most people skills are currently related to manual and unskilled labor but at the same time the community expels computer programmers. Hence, this work describes barriers, opportunities and efforts of girls interested in STEM areas.

In order to achieve the objective, the paper answers the following questions about the role of ICT for development in Turrialba:

- What is the trend of education and generation of enterprises?

- What are the obstacles and opportunities for students to be admitted in a CS program and to get a job locally?

- How has the original project intended to promote educational robotics evolved?

- What could be the options in education and employment for Turrialba in the computer age?

- How can the interaction between girls, robotics and STEM intertwine to generate girls' interest in those areas?

- What are cultural issues preventing girls from studying STEM related careers?

In the following sections we discuss other research related to our subject, the context of the labor market, education and ICT infrastructure, the gender gap in education and the workplace, the progression of reiterated attempts to find a digital future for the youth, especially girls, in rural areas, and conclusions.

\section{Background literature}

A previous research [6] about telecommuting opportunities in Turrialba (project number 510-B0108) studied the concept of technological capabilities due to the importance of ICT for the economic and social development as a whole. In this context, capability means abilities of individuals to learn concepts and accomplish tasks linked to information technology. That view is complemented with the capability of a collectivity to innovate in ICT.

Building on ideas of economist Amartya Sen about the particular interests of each person and the liberty for her evolution in a society, [7] adds the dimension of the capabilities of each person as part of a community whose goal is the collective benefit. Capabilities emerge from people, companies and communities; thus, a national system of innovation should promote the diffusion of technological capabilities.

The theory of diffusion of innovations [8] refers to the process to disseminate innovations for improving the skills that could be useful in communities to take advantage of new capabilities. That scenario is pivotal in this case because improving learning and knowledge of individuals about ICT could help generate collective welfare.

Another concept that is close to technological capability is "innovative capacity" or the ability to take advantage of the progress made by technical institutions, learning by doing, density of population and literacy to improve the level of human capital [9].

Innovations and technological capabilities could help generate social benefits and ICT should contribute to the improvement of human development. In [10], Human Development Index (HDI) is well renowned as a key measure on development that takes into account not only economics but also knowledge and a healthy life. Following this perspective, the author proposes a guide to analyze ICT in a social context in which human development and technological change interacts to increase productivity, innovation and welfare.

Albeit ICT is part of the human development, [11] confronting if solving problems as accessing trained teachers and potable drinking water in schools are priorities to be fulfilled before investing on ICT, especially in rural areas. In addition to that, these authors warn that the diffusion and transfer of ICT does not necessarily result in development. However, they propose Information and Communication Technology for Development (ICT4D) as a framework in which economic growth should be an engine for changing socioeconomic conditions. For them, that change could be achieved by means of the joint efforts of government, universities and industries.

\section{Context}

\subsection{Industries and technological literacy}

Most companies in Costa Rica are Small and Medium -Sized Enterprises (SMEs) and the scenario 
is similar in Turrialba where there are around 900 SMEs. In this region, most companies are not concerned about ICT, but 30 per cent of them faced difficulty when hiring skilled labor force and they will need more skilled workforce to meet market challenges, in the future. However, many agricultural products of Turrialba require little training and technical skills, currently.

Prior studies did not take into account the role of ICT to generate employment and improve workers' income in Turrialba [12]. Almost 40 per cent of companies do not have computers and technological literacy is low. The potential of innovation for private companies and public organizations is very low in the region.

Furthermore, of the total local workforce, around 70 per cent of workers have jobs in Turrialba but 18 per cent of them must commute every day to other regions. Many workers commuting from the region are professionals and technicians with no opportunities of getting appropriate jobs locally. Additionally, there is a weak feasibility for the development of telecommuting in Turrialba due to infrastructure problems there, lack of access to computers and Internet and a low level of local digital literacy.

\subsection{Education for the workplaces}

In Turrialba, only 27 per cent of people have attended high school and 60 per cent of the population attended only grammar school or has no qualifications at all.

In other words, 85 per cent of people aging from 12 to 17 years old attends high school, currently, but 11 per cent do not study or work [13]. Approximately, 90 per cent of students in high schools attend public ones and 65 per cent of those students finish high school successfully. However, a final standardized examination is applied to students enrolled in the last year of high school and the results in average, show grades under the minimum for biology, chemistry, physics and mathematics (less than 7.0 in a scale from 1.0 to 10), in Turrialba [14].

Furthermore, of the entire population of Turrialba, over the age of five, $13 \%$ have attended the university. Currently, 60 per cent of students attending colleges are enrolled in public one. In general terms, most people have studied almost eight years of school and that could be why companies looking for a more skilled labor force would not invest in the region.

In Costa Rica, only nine per cent of students from rural zones who are enrolled in college achieve a university degree [15]. Although, admission to public colleges increased 40 per cent in the last 12 years, the increase of admissions in campuses located in rural areas was only five per cent.
Paradoxically, many students who want to study programs related to science and technology are rejected. For the 2015 academic calendar school year, 560 students asked for admission to a computer science (CS) program but only 145 were admitted, in the main campus of the University of Costa Rica [16].

For instance, the Technology Institute of Costa Rica (ITCR), a public technological university, revealed that no more than 10 per cent of approximately 400 students graduating from high schools of Turrialba achieved a place in that university, in 2014 [17]. Most of the admitted students enrolled in electronics, computer sciences and industrial maintenance programs.

Additionally, more than 100 students ask for admission to CS in the campus of Turrialba yearly, but only around 35 freshmen are accepted each year (60 per cent of students who apply for admission are rejected annually). In five years, UCR rejected more than 300 students who asked to study CS in Turrialba.

Some rejected students could perform well in CS but the number of available spots does not increase nor takes into account the fact that, unfortunately, some accepted students switch from CS to other programs or fail and give up when facing troubles with math and programming. The performance of high schools students of Turrialba is weak in critical courses as physics and mathematics. Finally, 15 students graduate every year, in average, and most of them migrate from Turrialba because there are not enough job openings in the region.

\subsection{Infrastructure for a digital future}

Turrialba is a rural zone where 25 per cent of households are poor, 53 per cent of households have landline phones and each house has 1,8 cellular phones. In average, 37 per cent of households have computers and 24 per cent have an Internet connection. In addition, no more than 40 per cent of population use a computer or access Internet [18], and the digital divide in that region is one of the biggest in Costa Rica, a country with the smallest digital divide (urban-rural gap) in Latin America.

Since 1987, the Costa Rican Ministry of Public Education (MEP) has developed an Educational Technology Program (ETP) intended to build computer laboratories and train teachers for teaching computer topics in grammar and high schools. Turrialba had 21 grammar and high schools with 5000 students in the program by 2010 , around 40 per cent of all students in the region.

Currently, the public ETP comprises 19 computer laboratories and almost 500 computers for 136 grammar schools and 11 laboratories and 200 computers for 16 high schools. The program covers near 60 per cent of the students in the region. In 
addition, a private foundation provides 300 laptops for 9 grammar schools.

The number of students in kindergarten, grammar and high schools is around 15000 and statistics show the ratio is in the range of 5-10 students per computer in grammar schools and 11-15 in high schools. Between 60 to 70 per cent of computers have Internet connections.

Unfortunately, reduced infrastructure in schools is a limitation for spreading STEM interests and, in Turrialba, computers, broadband connections to Internet, classrooms, blackboards, desks, toilets and electricity are scarce in many schools. Most roads are in bad conditions, the transportation system of people and products is costly and these aspects are obstacles for students and for the investments of Small and Medium Enterprises (SME) and emerging jobs.

An additional problem is the capability of teachers to apply ICT in the education process, as they can generate enriched experiences in classrooms. Teachers skilled on ICT are crucial to foster students' aptitudes for STEM areas and collective capabilities for technological innovation. However, in Costa Rica, most universities graduate teachers that show contents to be memorized and they are more skilled on teaching method that in the subject to be taught [19]. That is particularly important in mathematics, subject that 43 per cent of teachers do not master. More specifically, the number of teachers skilled in ICT is also small in grammar and high schools in Turrialba.

By 2010, just 21 teachers were trained to apply ICT for teaching in Turrialba and most of contents that they thought were focused mainly on word processors and spreadsheets but not on programming nor on STEM topics. In that year, UCR and National University (UN), another public university, started a project to train 50 students in an ICT based program for teachers. The objective was providing ICT skilled teachers to local schools and other organizations in Costa Rica. However, most of graduates did not get local jobs and they were employed in schools out of Turrialba ("brain drain"). Another difficulty is that students admitted in the local campus of the university meet professors with low skills in ICT applied to education.

\subsection{Gap in the female presence in workplace and education}

Achieving gender equality and empowering women are goals included in the Millenium Development Goals, but there is a particular difficulty or gap for attracting female pupils to pursue technology-focused careers at higher education.
Studies of the U.S. Department of Labor, reveals that "by 2020, there will be 1.4 million computer specialist job openings. To reach gender parity by 2020 , women must fill half of these positions, or 700,000 computing jobs" [20]. If $30 \%$ of girls with exposure to CS will continue in the field, $4.6 \mathrm{M}$ adolescent girls will require some form of exposure to CS education until achieving gender parity in 2020.

In U.S. middle school, $74 \%$ of girls express interest in STEM careers, but only $0.3 \%$ of high school girls select CS as a college major. According to European Union statistics, around 25 per cent of tertiary-education students become enrolled in STEM as their main field of study and only 30 per cent of them are women.

"In the European Union, women accounted for 56 $\%$ of Knowledge Intensive Activities (KIA) sectors compared to only $46 \%$ in total employment" [21]. However, by 2009, women working in research and development (R\&D) were 35 per cent of that field of work and female researchers were a minority (32 per cent).

Female participation in the Costa Rican labor force (ratio of women to men) was 0,6 in 2010. Around 30 per cent of women are employed in a formal job, but the percentage for men with a formal job is 75 .

The salaries of people with technical education are higher than incomes of workers with uncompleted education. However, 42 per cent of women who completed technical high school are not an active part of workforce [22].

According to [23], in 2011, Costa Rica had 38742 workers in ICT sector of economy (2,3 per cent of working population in 897 companies) and 35 per cent were women. In Costa Rica, there are 3166 researchers and 1362 of them are women. From the total number of women that graduated in universities only 27 per cent of them graduated in the area of science, technology, engineering and mathematics (STEM).

The gender gap in Costa Rican education is important because 68 per cent of women finished grammar school but 73.7 per cent of men achieved that goal.

The scenario of gender gap in STEM related education is negative because girls face more difficulties in reading than boys and the situation becomes worse in mathematics and science.

In Costa Rica, approximately 47000 persons are studying or studied CS but only 8000 are women which incomes were smaller than that of their male counterparts salaries, by 2010 [24].

The trend is the number of women getting diplomas in CS decreases every year in contrast to graduations in basic sciences that steadily increase. 


\section{Looking for opportunities}

As previously mentioned, the UCR funded an educational robotics project intended to improve technological literacy of students and teachers. When public funds were over, Mr. Rogelio Nájera, an undergraduate student at UCR and a former participant in the original project, and Mr. Wilson Moya, a volunteer, opened a new club of robotics and also taught free courses about basic skills on digital literacy.

Eventually, the club of robotics for children became an organization called "Society for Digital Literacy" (Asociación Costarricense de Alfabetización Digital) intended to promote technological literacy as a way to help develop at digital future for Turrialba. Adopting a wider scope and looking beyond educational robotics, the organization became concerned about the role of ICT for development.

Opening new opportunities in the digital era is not the only pursuit of the organization because its scope includes promoting options about education, investment and employment for a rural region to change. Keeping part of its labor-intensive economic activities (e.g. SMEs in agriculture, commerce and services), the region could also become a knowledge-intensive community that integrates pieces of both realms.

However, the diffusion of innovations does no ensure that it will be able to overcome problems attached to poverty, and other aspects of the local context must be taken into account. Thus, transforming a society by means of ICT4D implies the integration of universities, companies and governmental agencies with the social generation of technological capabilities and human development as the north. Pursuing that integration, the "Society for Digital Literacy" also aims at designing a curriculum conducive to training technicians on cognitive robotics and computer support. This is an attempt to provide young people, particularly women, with an option to work in knowledge-intensive activities that has had the support of the Ministry of Sciences and Technology (MICIT).

Due to the limitations in dealing with the complexity of factors and people involved in the efforts, the Society decided to modify its organizational structure and evolve into a more dynamic one. So, in 2012, it became a company called CET-Bots, which continued using robotics as a way to gain traction in the quest of technological literacy in rural areas. Fig. 1 shows some students working with Arduino platform in CET-Bots office. By 2013, the German Corporation for International Cooperation (GIZ) provided technical and financial support that enabled CET-Bots to become a social enterprise.

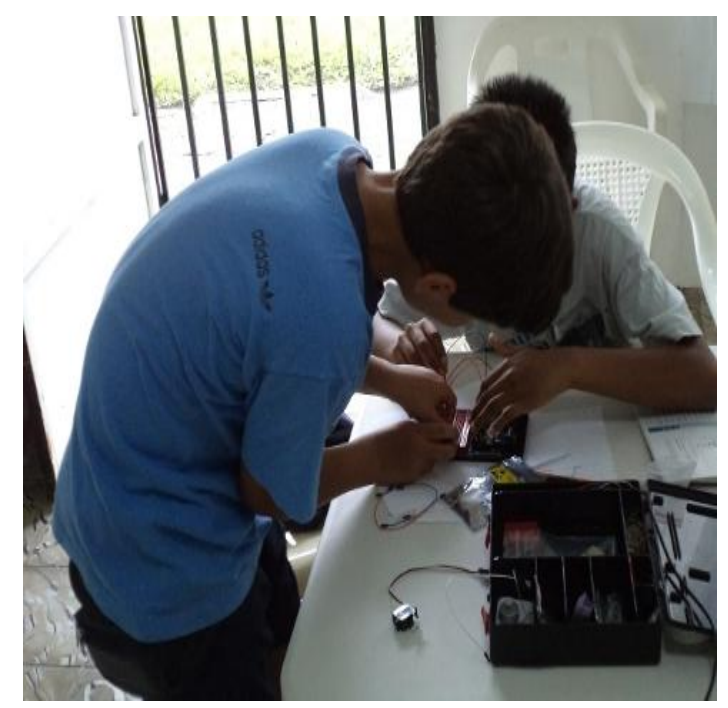

Figure 1. CET-Bots tries to improve the digital literacy of students by using generic platforms or robotics kits

CET-Bots developed activities in training people on ICT as well as supporting the creation of companies linked to ICT and engaged on the generation of more knowledge-intensive employment. Efforts on training included presentations and workshops about educational robotics in grammar and high schools and, as a result, two students learnt programming and started their own company focused on creating Web sites.

\subsection{Technical training}

As part of its training efforts, CET-Bots organized workshops on robotics in high schools and a group of students ended up creating an open source-based application to support disabled people. Regarding the importance of the students' initiative, GIZ funded a study of the feasibility of technical training on robotics that was conducted with 18 students. Opportunities of technical training are scarce in Turrialba and there is just one technical high school, but it focuses on networking more than on programming.

The analysis of the feasibility of a technical program on robotics in Turrialba is part of FACILIDAD, an initiative of GIZ for developing economy and employment opportunities in Central America. Goals of FACILIDAD are improving the competitiveness of enterprises and expanding employment opportunities for young people between 15 and 24 years old, and for women.

According to the study of feasibility [25], ICT ranks fifth among the areas with a high impact on the development of Turrialba, after tourism, commerce and service, education and industries linked to agriculture. Programming and other areas of ICT 
have low priority for the local market, and customer services, call centers, tourism, plumbing, building and industry are seen as more important options for economic growth.

However, basic digital literacy and e-commerce rank in first place regarding tasks to be performed in the workplace by people working for local SMEs, especially those related to commerce and services. Technical support for fixing computers and networks, managing Web sites and data and evaluating investments in hardware are also required.

Finally, the study suggested that students from a high school in a small town called Tres Equis, could be trained on computer support as a complement of their normal schedule (288 hours of training in two years). This option also received support by MEP, the municipality of Turrialba and a national public agency focused on technical training (Instituto Nacional de Aprendizaje, INA).

Instead of a core on programming for robotics, this option focused on training the students to be able to fix computers (maintenance of hardware and software), since that profile is the most needed for SME in Turrialba. Thus, the training should include not only teaching how to fix hardware problems but also basic contents related to Web design, programming, databases and networking. Three students succeeded and finished the technical training.

CET-Bots has had a limited but important impact not only at a technical level but also in promoting interest on college programs related to science, technology, engineering and mathematics. Such is the case of Roberto, a high school student who attended CET-Bots workshops. After that experience and once he finished high school, Roberto was admitted to, and started the coursework of, the CS program in the UCR campus in Turrialba, in 2015.

\subsection{Struggles for girls}

At the beginning of the process, in the computer laboratory of UCR, digital divide arose as a hard barrier for some girls coming from a grammar school close to the Turrialban landfill. They were not used to interacting with computers and faced hardships in programming. Quickly, the girls gave up and switched to improve their digital literacy by means of basic computer lessons. That was the first encounter of the project with the multiple and complex dimensions of digital divide, but more positive events came later.

During the second year of the project, several high schools students had to travel a few hours from a town in the outskirts to have the experience of engaging in educational robotics. They were in the last term of 11th grade, except a girl in 8th grade. Her name was Bertha; she was really engaged in the activities and, after her 9th grade, in 2013, she started studying electronics in a technical high school, located in the city of Cartago, $40 \mathrm{Kms}$. to the West of Turrialba. In her new technical high school, she joined a club in which 40 students spent their spare time learning robotics.

In 2014, she became an instructor in a grammar school that is near her high school. Every Saturday morning, with the support of a private foundation, Bertha and a programming teacher guide students (715 years old) in a seven week course. Until now, 50 students have learnt basic robotics in this club and 17 of the participants are girls.

Bertha has stayed linked to Cet-Bots activities for several years. According to her experience, robotics helps people improve their academic performance, the capabilities for discerning and problem-solving and the maturity to make decisions about the career they choose to pursue. Currently, Bertha's main goal is to study a BS on Digital Systems and Robotics Engineering in Mexico.

But Bertha is not the sole example of a proactive girl because while some high school students were working with Arduino platform in the Cet-Bots laboratory, a nine year girl tried successfully with that resource. She really wanted to foray in the field reserved for teenagers and her interest also opened the doors of Arduino to children from grammar schools. Arduino is used by high school and college students, but in this case the experience was fine with younger people and an additional plus was the fact that the budget required for that platform is less expensive that others in the market.

Fig. 2 shows girls involved in the educational robotics project, in a laboratory of the Atlantic Brach of the University of Costa Rica in Turrialba.

Parallel to CET-Bots a foundation called ADELY was created with the support of Women In Engineering (WIE), an international professional organization dedicated to promoting women engineers and scientists.

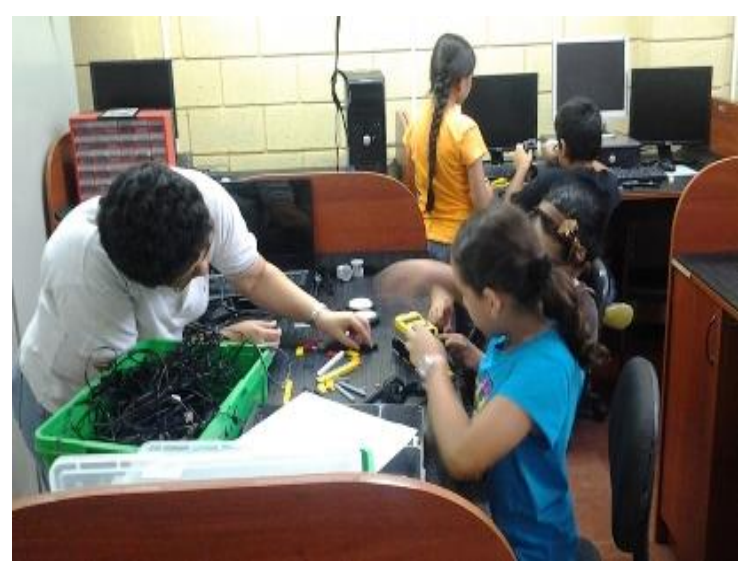

Figure 2. Girls have been involved in robotics since the project started in the university campus up to the present time 
The objective of ADELY is promoting girls from two remote small towns to study programming. ADELY, with the support of GIZ, gave 16 girls and women the opportunity of study programming in a public technical school. This experience showed that 95 per cent of women registered finished courses because they found studying as a way to get jobs that could be better options that being a housekeeper or a seller in a small store. In Turrialba, 51 per cent of the inhabitants are composed by women, but only 6 per cent of them form part of the formal workforce.

Getting jobs that are more knowledge intensive is not only a goal of women supported by ADELY and GIZ, because girls in colleges are looking for similar opportunities. However, female participation is just 30 per cent in CS programs deployed in the UCR Paraiso Campus (a university branch located near to Turrialba) and in a junior college in the same area. Annually, at least 10 men but only one woman achieve a bachelor degree program in CS, in the UCR campus in Turrialba.

Women interested on STEM careers faces discrimination because most people believe engineering is just for men, women are bad in math and girls working on mechanics or electronics are odd. To make matters worse, some girls' mothers frown upon the idea of their daughters in robotics contests.

\subsection{Working towards ICT for development}

An award in the National Congress of Innovation of Costa Rica recognized the efforts of CET-Bots, in 2014; although the impact of a small company with social compromise cannot be compared to the contribution of the public system of education.

At this point, CET-Bots is the current stage of an evolution from a club of robotics for some teachers and students to an approach of ICT4D for a rural region. Fig. 3 depicts the three phases of this process:

1. Diffusion of educational robotics as an innovation to improve technological literacy;

2. A transitional period to follow up the previous phase and extending the scope to understand and cope with regional challenges of ICT resulting from the regional context; and,

3. The integration of local agents and organizations to find a particular approach of ICT4D for Turrialba.

Its main contribution is trying to put ICT in perspective, in the context of human development, better education, more and better employment and getting several local sectors in tune with the challenges of knowledge-society that public universities and the government are not coping efficiently with in rural areas.

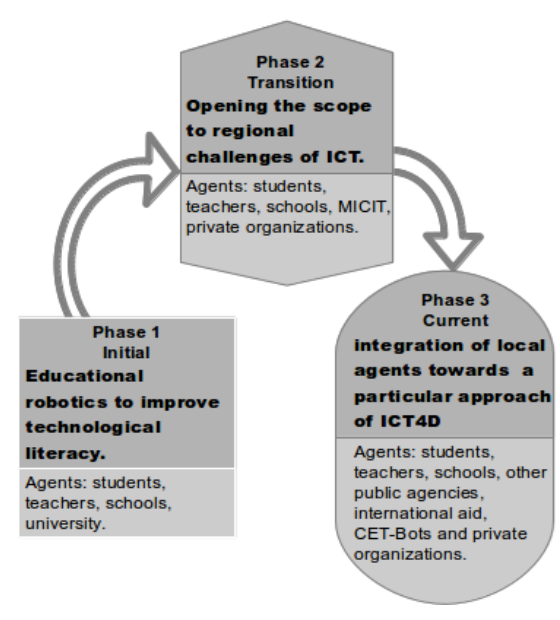

Figure 3. CET-Bots is part of a process with several phases

Public universities of Costa Rica have 12 regional branches and thousands of students are enrolled in $\mathrm{CS}$ and other STEM programs in those campuses. Each year, dozens of graduates leave rural towns where they studied, looking for jobs in the center of the country where ICT companies are concentrated. That situation is a local version similar to the "exodus" of skilled workers which is a problem faced by many countries.

A few ICT companies have opened offices in rural towns; for instance, two software developers hired a dozen of programmers in Turrialba, but that quantity of job openings just equates to the number of CS graduates in a year in the region.

In the future, one option is to continue with traditional and basic education for labor-intensive companies, while having a "brain drain" of ICT skilled workers; or, on the other hand, focusing on providing more years of schooling to more people and opening more CS spots in colleges, and promoting investments by knowledge-intensive companies at the same time.

Thus, education efforts must be complemented with the attraction of companies looking to take advantage of an educated workforce; otherwise, there will not be enough return on investment (ROI) to create a positive wellbeing for the community as whole.

\section{Conclusions}

Despite people believing that general education is fine, the actual average number of years of school attended by people in Turrialba is about eight years. Thus, most workers can be employed only by SMEs needing non-qualified workers for agriculture, 
commerce and textile industries (handmade baseballs, clothes, etc.).

Currently, in order to promote higher levels of employment, the government and politicians focus on attracting companies that are not highly interested on technician, professionals or skilled workers. Governmental agencies usually push people, especially women, to look for opportunities in traditional areas and markets full of competitors (handcraft, food, and clothing).

In addition, local opportunities of study and work in areas related to ICT are limited and nothing indicates this scenario will change any time soon. Despite the students' interest for STEM related options, local poverty and weak performance of high school students are barriers for people looking for opportunities in careers linked to STEM. Most of the well-educated technicians and professionals migrate or commute every day.

On the other hand, students also have some opportunities or advantages, such as the existence of a university campus in Turrialba with a CS program, which will accept at least 35 of them yearly, with no tuition to pay and even scholarships for a few of them, due to the financial support provided by public universities of Costa Rica. However, other obstacles are the low quality of teaching in areas related to STEM in high schools, the limited number of spots to study CS, the difficulty level of the CS program itself, and the fact that local companies do not need to hire computer programmers.

To face said scenario, the original educational robotics project has evolved along three phases from trying to improve digital literacy for some students and teachers to propose new options of training. The process helped not only look for new ICT-related opportunities for studying and working but also evaluate their short term feasibility according to local conditions.

Long-term, more interdisciplinary efforts are required for the full integration of an ICT4D Project into the characteristics of the region, taking into account aspects as environment, tourism, agriculture, commerce and services that this paper does not examine. That task implies a deeper analysis of the training on robotics in the context of attracting innovative companies and investors or in the scenario of an extended "brain drain" and the reproduction of trends.

Public investment in tertiary education in rural regions, especially on CS, will not translate into the desired return on investment in terms of social and economic transformations if the production structure does not change. Consequently, employment should significantly improve (number of job openings, higher quality, better salaries) to reduce emigration.

Changing minds and paying attention to the engineers coming from rural areas as a way to maximize local welfare will require public policies intended to attract investments on ICT to rural regions. Otherwise, there will not be a local direct return of the public investment made on their education nor an enhancement of the local economy, incomes and social development.

All in all, women interested on robotics usually do not love mathematics, but they see robotics not only as a hard challenge but also as a new opportunity for creating their workplaces. Otherwise, options of employment for them are too restricted. Along the years of this experience with educational robotics, the role of STEM for the development of women is depicting with more details now. The girls in robotics training prove that their performances are better than boys', despite difficulties for girls, as cultural and social discrimination, are hard. Then, supporting women in STEM areas could be more profitable than investing in men.

Unfortunately, public institutions do not coordinate nor have shared objectives about the economic and social development of Turrialba. Research projects about social and economic aspects to support decision making on regional development are both outdated and scarce. More specifically, research on ICT4D in the regions where public universities have a dozen of branches could help to improve economic and social conditions in those communities and overcome the factors that lead them to expel university graduates.

Lastly, Costa Rica is a country with many companies linked to ICT, but they lack human resources skilled on ICT and the participation of women is small and should increase.

Using the potential of ICT companies and ICTrelated jobs for contributing to improve welfare in Costa Rica is important because 50 per cent of economic resources belong to the richest 20 per cent of the population. In contrast, 20 per cent of inhabitants are poor and the Gini coefficient has increased in the last years. However, people of developing countries such as Costa Rica, and particularly those living in rural regions like Turrialba, must be aware that promoting technological capabilities and increasing productivity does not guarantee, per se, improving levels of human development.

\section{References}

[1] International Telecommunications Union, Measuring the Information Society (MIS) 2011, URL: http://www.itu.int/net/pressoffice/backgrounders/general/ pdf/5.pdf (Access Date: 18, June, 2015).

[2] K. Schwab and X. Sala-i-Martín, The Global Competitiveness Report 2014-2015: Full Data Edition, URL:http://www3.weforum.org/docs/WEF_GlobalCompet itivenessReport_2014-15.pdf (Access Date: 6, April, 2015). 
[3] A. Trejos and R. Arce, Desarrollo del talento humano: La clave para competir en la atracción de la inversión extranjera directa, CINDE-INCAE, 2012, URL: http://www.clubdeinvestigacion.com/usuarios/attachments/ download/23/competir-con-talento-humano-alberto-trejos .pdf (Access Date: 26, February, 2014).

[4] M. Santos, Desafíos de la educación en ciencia y tecnología, Estado de la Nación, 2011, URL: http://www.estadonacion.or.cr/files/biblioteca_virtual/017/ ICap6_17.pdf (Access Date: 25, February, 2015).

[5] A. Fernández and R. Del Valle, "Estimación de los determinantes de la desigualdad en los ingresos laborales de Costa Rica para el periodo 2001-2009", Revista de Ciencias Económicas, Volumen 29, Número 2, Instituto de Investigaciones en Ciencias Económicas, 2011, pp. 229245, URL: http://revistas.ucr.ac.cr/index.php/economicas/ article/download/7022/6707 (Access Date: 25 December, 2014).

[6] A. Rodríguez, "Educational robotics to improve digital literacy as a way to bridging rural workers and telecommuting", Proceedings of the International technology, education and development conference (Inted 2014), Spain, 2014, pp. 7112-7121.

[7] A. Carvajal, La innovación tecnológica como mecanismo de cambio tecnológico y su contribución al desarrollo, Edit. Antanaclasis, Costa Rica, 2010.

[8] E. Rogers, Diffusion of innovations, Fifth edition, Free Press, U.S.A., 2003.

[9] W. Maloney and F. Valencia, Engineers, Innovative Capacity and Development in the Americas, Policy Research Working Paper 6814, The World Bank Development Research Group, Macroeconomics and Growth Team, 2014, URL: http://www.econ.upf.edu/ gpefm/jm/pdf/paper/Engineers\%20IZA.pdf (Access Date: 15, September, 2014).

[10] E. Molera, Guía para el análisis del impacto de las tecnologías de la información y la comunicación en el desarrollo humano, Trabajo Fin de Grado, Universidad Politécnica de Madrid, 2008, URL: http://oa.upm.es/1045/1/PFC_ENRIQUE_CRESPO_MOL ERA.pdf (Access Date: 10, August, 2013).

[11] M. Georgsen and P. Zander, Changing education through ICT in developing countries, Aalborg University Press, Denmark, 2013, URL: http://vbn.aau.dk/ws/files/ 160291988/Changing_Education_OA_version.pdf (Access Date: 2, August, 2015).

[12] R. Arias, "Turrialba: Una Economía Local Entre la Crisis y el Desarrollo", Revista de Ciencias Económicas, Volumen 27, Número 1, Instituto de Investigaciones en Ciencias Económicas, 2009, pp. 209-231, URL: http://revistas.ucr.ac.cr/index.php/economicas/article/view/ 7128/6812 (Access Date: 29, April, 2013).

[13] Instituto Nacional de Estadística y Censos, Costa Rica: Indicadores de educación y de contexto, Costa Rica, 2013, URL: http://www.unicef.org/lac/IndicadoresRegiona lesfinal-web.pdf (Access Date: 8, January, 2015).
[14] M. Jiménez, A. Tapia, R. Riggioni and E. Coto, Estadísticas relevantes de Turrialba: situación del cantón al 2012, Universidad de Costa Rica, Costa Rica, 2015.

[15] Programa Estado de la Nación, Cuarto Informe Estado de la Educación, Costa Rica, 2013, URL: http://www.estadonacion.or.cr/informe-iv-estado-educaci on (Access Date: 30, November, 2015).

[16] A. Rodríguez, "Cortes de ingreso presentan una variable cambiante", Enero 2014, consultado en $\mathrm{http} / / /$ semanariouniversidad.ucr.cr/universitarias/cortes-deingreso-presentan-una-variable-cambiante/ (Access Date: 30, June, 2015).

[17] Oficina de admisión y registro del Instituto Tecnológico de Costa Rica, Datos acerca de admisiones de colegios de Turrialba, Costa Rica, 2014.

[18] Programa Estado de la Nación e Instituto Nacional de Estadística y Censos, Indicadores cantonales Cartago, Costa Rica, 2013, URL: http://www.inec.go.cr/ A/MS/ Censos/Censo\%202011/SIM/C1/06.\%20Indicadores\%20ca ntonales\%20Cartago/Indicadores\%20Cantonales.pdf (Access Date: 6, June, 2014).

[19] R. Jiménez, Educación pública en Costa Rica: políticas, resultados y gasto, Academia de Centro América, 2014, URL: http://www.academiaca.or.cr/wp-content/ uploads/2014/08/Analisis-Ronulfo-6-2014C.pdf (Access Date: 16, March, 2015).

[20] Girls Who Code, Path to success, URL: http://girlswhocode.com/about-us/ (Access Date: 11, December, 2014).

[21] European Union, Science, technology and innovation in Europe Pocketbooks, 2012, http://ec.europa.eu/eurostat/ documents/3930297/5967670/KS-GN-12-001-EN.PDF/ 5ee2a4e8-68c0-4b22-a061-b8e7d8cc8ec1?version=1.0 (Access Date: 9, July, 2014).

[22] J. León, Cuarto Informe Estado de la Educación, Informe final Educación Técnica, 2012, URL: http://www.estadonacion.or.cr/files/biblioteca_virtual/educ acion/004/leon-educacion-tecnica.pdf (Access Date: 3, February, 2014).

[23] A. Quesada, "Medición del sector TIC en Costa Rica". Programa Sociedad de la Información y el Conocimiento. San José, CR. 2013. URL: http://www.prosic.ucr.ac.cr/sites/default/files/documentos/ cap5_1.pdf (Access Date: 22, March, 2014).

[24] V. Alvarez, Status of Women's Participation in Science and Technology in Costa Rica: Women Informatics, in XXXVIII Conferencia Latinoamericana en Informática (CLEI), 2012.

[25] J. Guzmán, S. Francis and V. Sánchez, Educación para un buen trabajo: robótica, Desarrollo curricular para un técnico en robótica cognoscitiva, informe de primera etapa, Universidad de Costa Rica, Universidad Nacional, Instituto Tecnológico de Costa Rica, Fundación Amanda Rodríguez and Federal Ministry of Economics and Technology of Germany, Costa Rica, 2014. 